\title{
The Impact of Humorous Video in Short Term Memory
}

\author{
(Student of Faculty of Medicine, Jenderal Achmad Yani University)
}

\author{
Daswara Djajasasmita* \\ Department of Physiology, Faculty of Medicine \\ Jenderal Achmad Yani University \\ Cimahi, Indonesia \\ *daswara.dj@fk.unjani.ac.id \\ Dessi Suri Astutie \\ Faculty of Medicine \\ Jenderal Achmad Yani University \\ Cimahi, Indonesia
}

\author{
Andri Anugerah Kusuma \\ Department of Neurosurgery \\ RS TK II Dustira \\ Cimahi, Indonesia
}

\author{
Fahmi Nur Hidayatullah \\ Faculty of Medicine \\ Jenderal Achmad Yani University \\ Cimahi, Indonesia \\ fahminhdr@gmail.com
}

\begin{abstract}
Humans cannot be separated from the process of remembering. The process of remembering is closely related to memory, one of which is short-term memory. A new student at the Faculty of Medicine is required to be able to manage information well. Some ways can be used to help someone improve their short-term memory, one of which is with a humorous display. The purpose of this study was to determine the effect of humor in improving short-term memory in new students at the Faculty of Medicine. This study uses a quasiexperimental method, by comparing short-term memory before and after watching humorous shows using the Digit Span Test. The results of research with the forward method obtained an average of 5.37 before watching humor shows and 6.17 after watching humor shows. Also, by using the backward method, the average before watching humor shows is $\mathbf{5 . 5 0}$ and after watching humor shows is 6.50 . The results of the p-value showed significant results $(p<0.05)$. This is because these humorous displays can stimulate the amygdala to send signals in the form of positive emotional experiences that will produce endorphins. These endorphins will cause alpha waves to become dominant and frontal lobe function will be activated, so that a person will feel calm and comfortable, and it is easy to concentrate. Based on this, it can be concluded that watching humorous shows can improve short-term memory.
\end{abstract} video

Keywords-first year students, Short term memory, Humorous

\section{INTRODUCTION}

Humans cannot be separated from the process of remembering. The ability of each individual in the process of remembering varies widely. A good memory can certainly make it easier for someone to carry out their daily activities.
The difference between the teaching system in Senior High Schools (SMA) and lectures requires new students to be able to manage the information they receive properly so that it can be used when needed $[1,2]$.

Cognitive language comes from the Latin "Cogitare" which means thinking. In the Big Indonesian Dictionary, cognitive means everything related to or involving cognition, or based on empirical factual knowledge. In psychology, cognitive includes all forms of recognition that include every human mental behavior related to problems of understanding, understanding, attention, thinking, considering, processing information, solving problems, deliberating, imagining, estimating, thinking, believing, and so on. Students at the Faculty of Medicine, General Achmad Yani (Unjani) University are required to have good cognitive functions that can help them in the process of remembering. Poor cognitive function can lead to decreased academic achievement [3].

The process of remembering is closely related to memory. In everyday life, humans experience touch, see, smell, and hear something. The information experienced and felt will be given a name and will be stored in memory or memory. Memory helps in retrieving, storing, processing, and retrieving stored information for reuse [4].

Short-term memory is the memory that lasts a few seconds or a few minutes at most. Short-term memory can be described as a person's ability to memorize 7 to 10 facts for a few seconds to a few minutes, but will only last as long as a person is constantly thinking about those facts. Medium-term memory can last minutes or even weeks. This memory will occasionally be lost unless the memory trace gets activated sufficiently so that it becomes more permanent, which is then classified as 
long-term memory. Long-term memory can be formed by repeatedly activating short-term memory which will cause chemical, physical, and anatomical changes in the synapses that are responsible for long-term type memory [4,5].

The film is one of the audio-visual media which is classified as mass communication, so that film can also convey messages to the public. One of the various functions that mass media has is entertaining. Comedy films place humor as the main content that can entertain and attract attention, and create interest for someone, with a reaction, namely laughter [6].

Humor on learning has been studied by the American Psychological Association, where they distributed questionnaires to 114 students, and it was found that 112 people said they enjoyed learning more when an instructor used humor in the classroom. It was also found that 81 people said they wanted to learn more when the instructor used humor in the classroom [7].

Students at the Kulliyyah of Islamic Revealed Knowledge and Human Sciences Malaysia have also researched the relationship between humor and good recall in 2013, and 87 participants obtained a significant value, namely with a p-value of 0.001. Ningrum Baha Lathifah, Amir Hasan Ramli, and Faizah have also researched the relationship of humorous impressions to short-term memory in new students, where they researched Brawijaya University Psychology students in 2015 involving 50 participants with a significant value of 0.001 which is smaller than 0.05 , this indicates that there is an effect of humorous impressions on memory abilities. This study proves that there is an effect of humor on memory enhancement $[1,2,8,9]$.

Based on previous research, the short film directed by Raditya Dika entitled "Malam Minggu Mikko" is a program that can evoke a sense of pleasure and is easy to understand based on the respondents' opinions [6].

When laughing, the body produces endorphins which have the effect of reducing pain, lowering stress hormones, and increasing immunity, thereby reducing the stressful conditions experienced by the subject. Endorphins are produced by the pituitary gland and hypothalamus, which are released during laughter. Endorphins are released into the blood from the pituitary gland and into the brain from hypothalamic neurons. This hormone gives a feeling of pleasure and a good mood. The happiness hormone can be produced in certain circumstances, such as eating, exercising, listening to classical music, thinking positive things, and meditating [10].

Short-term memory is often measured in a memory span, which is a single presentation of several items in the form of numbers that can be repeated right after serving. This number test is called the Digit Span test. Herman Ebbinghaus is the first cognitive scientist to show how the digit span can be used as an experimental paradigm for investigating memory and learning. A number range is the name of a psychological test to assess working memory/ability to retain short-term memory.
The Digit Span test consists of two sub-tests: Digits Forward and Digits Backward. Each there are seven series [11].

In the Digit Forward test, an examiner pronounces a series of numbers at a rate of one digit per second, then the respondent is asked to repeat the sequence of numbers as mentioned by the examiner. If the respondent answers correctly in one series, the test is continued to the next series with one more number up to a maximum of nine points. In the Digit Backward test, it is done by mentioning all the numbers that have been prepared, then asking the respondent to repeat the series of numbers in reverse order up to a maximum of eight numbers [11].

This Digit Span Test aims to prove the theory that a person can store 7 to 10 things in their short-term memory. The serial order is the total number of digits drawn correctly regardless of the subtest used. This Digit Span assessment was also conducted by Annisa Putri Wulansari to measure the effect of brain exercise on short-term memory of final year students at the Faculty of Medicine, Unjani [12].

Researchers want to examine the relationship between humorous displays and short-term memory in new students of the Faculty of Medicine, General Achmad Yani, class of 2019 because this research is still very rarely conducted and there is no definite discussion about how the effect of humorous shows on short-term memory using the Digit Span Test.

\section{METHODS}

This study used a cross-sectional method with a pre-test and post-test design, namely by comparing the short-term memory before and after watching the humorous show entitled "Malam Minggu Mikko" using the Digit Span Test. The subject in this study was a new student at the Faculty of Medicine, Unjani class 2019. Sampling in this study, using simple random sampling.

The research tools and materials used in this study were the concent informed sheet, a laptop, a humorous video in the form of a short film entitled "Malam Minggu Mikko", writing tools, a stopwatch, and a digit span test memory test sheet to test memory.

This research begins with meeting all potential respondents, as many as 241 people. The researcher explained in advance the aims and objectives of the research to be carried out to the new students of the 2019 class, as well as how prospective respondents who would participate in this research would be selected. After the explanation of this research was carried out, the researcher asked all potential respondents if their NIM was randomly selected, whether these potential respondents were willing to participate in this research or not.

241 new students will be random through NIM using the help of Microsoft Excel, where all NIM will be entered into a table list, then use the formula = RANDBETWEEN (top; bottom) which functions to generate random numbers in the specified range of numbers desired. In this way, you will get 30 
NIMs who will be respondents as a minimum sample required to be taken in this study.

Students who met the inclusion criteria were called upon to take a memory test. Each respondent will be given another explanation regarding the procedure and purpose of this study. Then the respondent will be asked to fill out and sign the informed consent sheet. Respondents will be explained in advance to better understand the rules in answering this shortterm memory test instrument. After the respondents understood how to fill in this test, then the research began, by doing a pretest first. After the pre-test is complete, it will be continued with the display of humorous shows which last approximately 8 minutes. After airing, it will be continued again by conducting a post-test.

The research data obtained regarding the effect of humor impressions with short-term memory can be analyzed using statistical tests, namely, the paired " $t$ " test if the data is normally distributed, if not normally distributed then using the Wilcoxon test. Data distribution normality test using Kolmogorov-Smirnov. This test is used because in this study there is one subject with two treatments, namely before and after watching humorous shows. The data were then collected and processed using one of the SPSS statistical software and presented in tabular form.

\section{RESULTS AND DISCUSSION}

This study aims to determine the effect of humorous impressions in increasing short-term memory for new students of class 2019 at the Faculty of Medicine, Jenderal Achmad Yani University which was held in December 2019. Research respondents were 30 people who met the study inclusion criteria.

This research was followed by new students of the 2019 class consisting of 17 women (56.7\%) and 13 men (43.3\%), with the largest age being 18 years, totaling 18 people or about $60 \%$ of all students. who are the respondents.

\section{A. Figure Span Test Before and After Watching Humor}

TABLE I. AN OVERVIEW OF THE DIGIT SPAN TEST BEFORE AND AFTER WATCHING HUMOROUS SHOWS FOR NEW STUDENTS OF ClASS 2019 AT THE FACULTY OF MEDICINE, JENDERAL ACHMAD YANI UNIVERSITY

\begin{tabular}{|l|l|l|l|l|}
\hline \multirow{2}{*}{ Digit Span } & \multicolumn{4}{|c|}{ Methode } \\
\cline { 2 - 5 } & \multicolumn{2}{|c|}{ Forward } & \multicolumn{2}{c|}{ Backward } \\
\cline { 2 - 5 } & Before & After & Before & After \\
\hline Mean & 5,37 & 6,17 & 5,50 & 6,50 \\
\hline SD & 0,99 & 0,83 & 0,57 & 0,57 \\
\hline Median & 6,00 & 6,00 & 6,00 & 7,00 \\
\hline Minimum & 4,00 & 5,00 & 4,00 & 5,00 \\
\hline Maximum & 7,00 & 7,00 & 6,00 & 7,00 \\
\hline
\end{tabular}

Table 1 above shows that the digit span score with the forward method before watching humor shows has a mean value of 5.37, a standard deviation of 0.99 , a median of 6.00 , a minimum value of 4.00 , and a maximum value of 7.00 . Meanwhile, after watching humor shows, it has a mean of 6.17 , a standard deviation of 0.83 , a median of 6.00 , a minimum value of 5.00, and a maximum value of 7.00. This shows that there is an increase in memory on the digit span test with the forward method.

The digit span score in the backward method before watching humor shows has a mean value of 5.50, a standard deviation of 0.57 , a median of 6.00 , a minimum value of 4.00 , and a maximum value of 6.00. Meanwhile, after watching humor shows, the digit span test has a mean value of 6.50 , a standard deviation of 0.57 , a median of 7.00 , a minimum value of 5.00, and a maximum value of 7.00. This shows that there is an increase in memory in the digit span test using the backward method.

Based on the results of the study, 23 new students experienced an increase in the results of the tests carried out the first time, both pre-test and post-test, 4 people did not experience a significant increase, and 3 other people did not experience any increase in test results, both pre-test. and posttest. Even so, the average obtained in the two test methods carried out showed an increase in the average between before and after new students were given a stimulus in the form of a humorous show.

The normality test that has been carried out in this study shows that the data distribution of the digit span test before and after humor shows with the forward and backward methods are all not normally distributed $(\mathrm{p}<0.05)$.

\section{B. The Effect of Humor Impressions on Short-Term Memory}

TABLE II. THE EFFECT OF HUMOROUS DISPLAYS ON SHORT-TERM MEMORY IN NEW STUdENTS AT THE 2019 UnJANI FACULTY OF MEDICINE

\begin{tabular}{|l|l|l|l|l|l|}
\hline Variables & N & Mean & SD & T (T-Test) & P-Value \\
\hline Forward & 30 & 0,8 & 0,61 & 7,18 & 0,00 \\
\hline Backward & 30 & 1,00 & 0,69 & 7,88 & 0,00 \\
\hline
\end{tabular}

Based on Table 2, the test results using the Wilcoxon test statistics show that 30 respondents participated in this study. Using the forward method, there are changes with an average of 0.8 , while using the backward method there are changes with an average of 1.00. From the results of the statistical test, there is a significant value of $\mathrm{p}$ on the digit span test with the forward and backward methods of $0.00<\alpha(0.05)$, so it can be concluded that there is a significant influence between humorous displays on the short-term memory of new students of class 2019.

Based on the results of this study, it can be concluded that the results obtained by researchers have similarities with the results of previous studies that have been conducted by students at Kulliyyah of Islamic Revealed Knowledge and Human Sciences Malaysia, where a significant value was obtained, namely with a p-value of 0.001 . Other research was conducted by Ningrum Baha Lathifah, Amir Hasan Ramli, and Faizah, where they researched Brawijaya University Psychology students in 2015 with a significant value of 0.001 $[1,8]$. 
The increase in short-term memory in new students is due to the input that comes in through the eyes and ears from watching humorous shows, where this sensory input will generate positive emotional experiences that produce endorphins. Where endorphins will cause alpha waves and frontal lobe waves to be activated, so that a person feels calm, comfortable, and happy, and can increase motivation. Alpha waves can also cause increased immunity, a stable heart rate, and increased sensory capacity. Where the activation of alpha waves can cause the mind to feel relaxed and easy to learn due to increased concentration. This concentration can improve short-term memory in a person $[1,4,10]$.

\section{CONCLUSION}

In this study, it can be concluded that there is an increase in the average score of the digit span test, whereby using the forward method the average score before watching humor shows is 5.37 and after watching humor shows is 6.17. Also, by using the backward method the average digit span score before watching humor shows is 5.50 and after watching humor shows is 6.50, and there are significant results between the effect of humor shows on the short-term memory of new students of class 2019 at the Faculty. Medicine Unjani Class 2019. This shows that there is an influence between humorous displays and short-term memory.

\section{REFERENCES}

[1] N. Lathifah, A. Ramli, and Faizah, "Pengaruh Tayangan Humor Terhadap Short Term Memory Pada Mahasiswa Baru," MEDIAPSI, vol. 1, pp. 10-6, 2015.

[2] B. Maulina and D. Sari, "Derajat Stres Mahasiswa Baru Fakultas Kedokteran Ditinjau Dari Tingkat Penyesuaian Diri Terhadap Tuntutan Akademik," J Psikol Pendidik Konseling, vol. 4, pp. 1-5, 2018.

[3] Sutarto, "Teori Kognitif dan Implikasinya Dalam Pembelajaran," Islam Couns, vol. 1, no. 02, pp. 1-2, 2017.

[4] A.C. Guyton and J.E. Hall, Buku ajar fisiologi kedokteran. EGC, 2019.

[5] T. Dharmawan, "Musik Klasik dan Daya Ingat Jangka Pendek Pada Remaja," JIPT, vol. 03, 2015.

[6] V.D. Sugiarto, "Teknik Humor dalam Film Komedi yang Dibintangi oleh Stand Up Comedian," J Ekomunikasi, vol. 4, pp. 1-2, 2016.

[7] D. Appleby, "Use Hunor In The College Classroom," Am Psychol Assoc., vol. 77, no. 6, pp. 1121-34, 2018.

[8] Z. Badli and M. Dzulkifli, "The effect of humour and mood on memory recall," ScienceDirect, pp. 252-7, 2013.

[9] V. Edlyn, Pengaruh Tayangan Humor Terhadap Peningkatan Memori Jangka Pendek. Universitas Kristen Maranatha, 2015.

[10] D.S. Haruyama, The Miracle Of Endorphin. Nukman E, editor. Tokyo: Qanita, 2015, pp. 88-92.

[11] Penney, Encyclopedia of Clinical Neuropsychology. Amerika Serikat: Spinger-Verlag, 2010, pp. 1-7.

[12] A. Wulansari, Pengaruh Senam Otak (Brain Gym) Terhadap Memori Jangka Pendek Mahasiswa Tingkat Akhir Fakultas Kedokteran Universitas Jenderal Achmad Yani. Universitas Jenderal Achmad Yani; 2018. 